\title{
Using data assimilation to investigate the causes of Southern Hemisphere high latitude cooling from 10 to $8 \mathrm{ka} \mathrm{BP}$
}

\author{
P. Mathiot ${ }^{1,7}$, H. Goosse ${ }^{1}$, X. Crosta ${ }^{2}$, B. Stenni ${ }^{3}$, M. Braida ${ }^{3}$, H. Renssen ${ }^{4}$, C. J. Van Meerbeeck ${ }^{5}$, \\ V. Masson-Delmotte ${ }^{6}$, A. Mairesse ${ }^{1}$, and S. Dubinkina ${ }^{1}$ \\ ${ }^{1}$ Université catholique de Louvain, Earth and Life Institute, Georges Lemaître Centre for Earth and Climate Research, \\ Place Louis Pasteur, 3, 1348 Louvain-la-Neuve, Belgium \\ ${ }^{2}$ UMR-CNRS 5805 EPOC, Université Bordeaux 1, Talence, France \\ ${ }^{3}$ University of Trieste, Dipartimento di Matematica e Geoscienze, Trieste, Italy \\ ${ }^{4}$ Cluster Earth \& Climate, Department of Earth Sciences, Vrije Universiteit Amsterdam, the Netherlands \\ ${ }^{5}$ Caribbean Institute for Meteorology and Hydrology, Husbands, St. James, Barbados \\ ${ }^{6}$ Laboratoire des Sciences du Climat et de l'Environnement, UMR8212, CEA-CNRS-UVSQ/IPSL, Gif-sur-Yvette, France \\ ${ }^{7}$ British Antarctic Survey, Natural Environment Research Council, Cambridge, UK
}

Correspondence to: P. Mathiot (pierre.mathiot@ bas.ac.uk)

Received: 26 October 2012 - Published in Clim. Past Discuss.: 15 November 2012

Revised: 11 March 2013 - Accepted: 11 March 2013 - Published: 3 April 2013

\begin{abstract}
From 10 to $8 \mathrm{kaBP}$ (thousand years before present), paleoclimate records show an atmospheric and oceanic cooling in the high latitudes of the Southern Hemisphere. During this interval, temperatures estimated from proxy data decrease by $0.8^{\circ} \mathrm{C}$ over Antarctica and $1.2^{\circ} \mathrm{C}$ over the Southern Ocean. In order to study the causes of this cooling, simulations covering the early Holocene have been performed with the climate model of intermediate complexity LOVECLIM constrained to follow the signal recorded in climate proxies using a data assimilation method based on a particle filtering approach. The selected proxies represent oceanic and atmospheric surface temperature in the Southern Hemisphere derived from terrestrial, marine and glaciological records. Two mechanisms previously suggested to explain the 10-8 ka BP cooling pattern are investigated using the data assimilation approach in our model. The first hypothesis is a change in atmospheric circulation, and the second one is a cooling of the sea surface temperature in the Southern Ocean, driven in our experimental setup by the impact of an increased West Antarctic melting rate on ocean circulation. For the atmosphere hypothesis, the climate state obtained by data assimilation produces a modification of the meridional atmospheric circulation leading to a $0.5^{\circ} \mathrm{C}$ Antarctic cooling from 10 to $8 \mathrm{ka} \mathrm{BP}$ compared to the simulation without data assimilation, without congruent
\end{abstract}

cooling of the atmospheric and sea surface temperature in the Southern Ocean. For the ocean hypothesis, the increased West Antarctic freshwater flux constrainted by data assimilation $(+100 \mathrm{mSv}$ from 10 to $8 \mathrm{ka} \mathrm{BP})$ leads to an oceanic cooling of $0.7^{\circ} \mathrm{C}$ and a strengthening of Southern Hemisphere westerlies $(+6 \%)$. Thus, according to our experiments, the observed cooling in Antarctic and the Southern Ocean proxy records can only be reconciled with the reconstructions by the combination of a modified atmospheric circulation and an enhanced freshwater flux.

\section{Introduction}

Over Antarctica, water stable isotope records from deep ice cores show a temperature optimum around $12-10 \mathrm{ka} \mathrm{BP}$ (thousand years before present, the notation ka is used hereafter) (Masson-Delmotte et al., 2000, 2011; Stenni et al., 2011), followed by a large cooling of about $1^{\circ} \mathrm{C}$ from 10 to $8 \mathrm{ka}$ (Fig. 1), which is the strongest millennial Antarctic temperature fluctuation of the last $10 \mathrm{ka}$. The mechanisms responsible for this variation have not yet been explored and could be related to changes in atmospheric and/or oceanic circulation, in relationship with changes in orbital forcing and deglacial meltwater fluxes. 

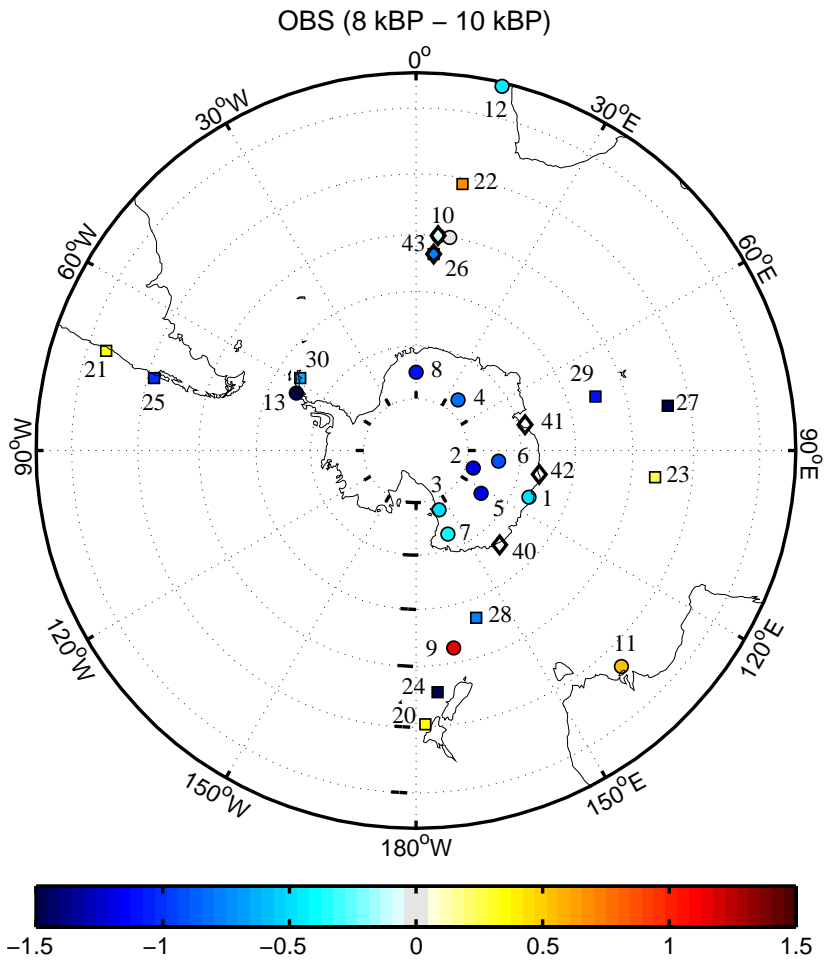

Fig. 1. Available early Holocene temperature data at high southern latitudes. Colors show the temperature differences between 8 and $10 \mathrm{ka}$. Circles correspond to the proxy data used in the simulations with data assimilation. Squares depict available proxy data that are not used in the simulations with data assimilation, because of either low resolution or not covering the reference or fossil periods (cf. Sect. 2.3 for more explanation). Both types of data are taken into account to validate the simulations. Diamonds refer to qualitative data that are not used to compute MAE in Table 3. A description of these proxies is shown in Tables $1 \mathrm{a}, \mathrm{b}$ and $\mathrm{c}$.

In Antarctic coastal regions, only a few quantitative and qualitative sea surface temperature (SST) and sea ice reconstructions are available. They are based on $\mathrm{TEX}_{86}$ (tetraether index of 86 carbon atoms) in the West Antarctic Peninsula (Shevenell et al., 2011) and Adélie Land (Kim et al., 2008, 2012), on marine diatoms in Adélie Land (Crosta et al., 2008; Denis et al., 2009) and in Prydz Bay (Denis et al., 2010; Barbara et al., 2010) and on lake diatoms in Wilkes Land (Verkulich et al., 2002). The reconstructions from Wilkes Land, Adélie Land and the Antarctic Peninsula similarly suggest a cooling between 10 and $8 \mathrm{ka}$. The cooling along the Wilkes Land and Adélie Land has been related to glacier advance and sea ice expansion, which provided a positive feedback on East Antarctic atmospheric temperature. Along the Antarctic Peninsula, the cooling around $8 \mathrm{ka}$ was suggested to reflect a decrease of southern westerlies wind (SWW), which led to a decrease of circumpolar deep water (CDW) intrusion onto the continental shelf and subsequently a surface cooling (Shevenell et al., 2011).
Conversely, diatom-based reconstructions of sea ice and oceanic temperatures from Prydz Bay suggest that surface waters off Princess Elizabeth Land were warmer at $8 \mathrm{ka}$ compared to $10 \mathrm{ka}$ (Barbara et al., 2010; Denis et al., 2010). This regional warming was suggested to be related to an increase of the CDW intrusion into the shelf between 10 and $8 \mathrm{ka}$ due to a more southern position of the Antarctic Circumpolar Current (ACC).

In the Southern Ocean (SO), in the area between the Antarctic slope front (ASF) and the subtropical front (STF), geological records generally show a large cooling from 10 to $8 \mathrm{ka}$, similar to the one estimated at the surface of Antarctica (Bianchi and Gersonde, 2004; Hodell et al., 2001; Crosta et al., 2005; Panhke and Sachs, 2006; Nielsen et al., 2004). This shift is thought to be caused by a northward migration of oceanic fronts (south ACC front, polar front, sub-Antarctic front or STF). Associated with this cooling event, diatom records in the marine cores located south of the polar front suggest a northward migration of the sea-ice front during the 10-8 ka period (Nielsen et al., 2004; Bianchi and Gersonde, 2004; Hodell et al., 2001).

By contrast, one pollen record in the Campbell Island area (McGlone et al., 2010) shows a clear warming from 10 to $8 \mathrm{ka}$. These authors explained this feature by an equatorward migration and a strengthening of the SWW over Campbell Island and, consequently, an increase in the poleward meridional heat transport. This is, however, inconsistent with nearby SST reconstructions (Crosta et al., 2004; Pahnke and Sachs, 2006), which depict a clear oceanic cooling during the 10-8 ka period (Fig. 1).

This overview of existing early Holocene SH (Southern Hemisphere) high latitude temperature records shows a large atmospheric and oceanic cooling from 10 to $8 \mathrm{ka}$. However, the causes of this cooling are not well known. Based on transient climate simulations, mechanisms responsible for Holocene climate variability have been investigated. Using an intermediate complexity ocean-sea ice-atmosphere model without fresh water flux (fwf) forcing due to ice sheet melting, Renssen et al. (2005) showed that the long-term SH high latitude temperature trend during the Holocene $(9 \mathrm{ka}$ to present) can be explained by a combination of a delayed response of the Southern Ocean-Antarctic climate to local orbitally-driven insolation changes, modulated by the memory of the system. In their simulations, changes in meridional heat fluxes had a negligible impact, as a result of small change in SWW.

Changes in large-scale ocean circulation, related to meltwater fluxes in the northern or southern latitudes, can also affect both atmospheric and sea surface temperatures in the high southern latitudes. Indeed, the last glacial period is marked by small maxima in Antarctic temperature associated with a bipolar seesaw with Northern Hemisphere temperature (causing an opposite temperature response at both poles, e.g., Crowley, 1992; Stocker, 1998; Capron et al., 2010). Similar mechanisms were suggested to account for 
early interglacial Antarctic warmth (Shakun et al., 2012; Stenni et al., 2011; Masson-Delmotte et al., 2010; Holden et al., 2010). Such bipolar seesaw mechanism inducing austral warmth may be driven by the impact of the final Laurentide meltwater flux on the Atlantic meridional overturning circulation. Additionally, changes in the intensity of convection in Labrador Sea could also influence high southern latitudes through advective oceanic connections (causing then delayed temperature changes of the same sign in both hemispheres, Renssen et al., 2010) and could overwhelm the effect of the bipolar seesaw in the case of shut down of the Labrador Sea deep water formation. This could ultimately dominate the impacts of local insolation changes suggested by Renssen et al. (2005) and drive Southern Ocean climate evolution (Renssen et al., 2010).

Alternatively, the high southern latitude climate can also be strongly affected by the melting rate of the Antarctic ice sheet, as shown, for instance, in idealized modeling studies (Swingedouw et al., 2009). Such local freshwater forcing induces a surface atmospheric and oceanic cooling in the Southern Hemisphere, with the largest signal in the Southern Ocean, where an increase of sea ice cover is simulated, as well as a strengthening of westerlies and easterlies. So far, this mechanism has not been investigated as an explanation for the early Holocene changes around Antarctica.

To combine the information provided by proxy data and a climate model, data assimilation methods have been adapted to the long timescales, providing estimates that are compatible with model physics and available data (e.g, Widmann et al., 2010). However, using data assimilation with a highresolution climate model is not practically possible today for a long timescale because this type of simulation would require a too large amount of CPU time. Consequently, data assimilation has been applied here with an earth system model of intermediate complexity (EMIC). Although the full complexity of the system is not resolved in an EMIC model, it is possible to carry out multiple simulations or large ensembles with different initial conditions and different combinations in external forcing within a reasonable time. This allows testing the physical plausibility of hypotheses suggested to explain signals derived from proxy data. However, due to the coarse resolution and simplified model physics, results are associated to large uncertainties. For example, Spence et al. (2012) show that the horizontal resolution could be crucial to define the right water mass pathways, properties, and the related climatic effects. This leaves room for potential inconsistencies between model results and empirical reconstructions.

In the present study, using data assimilation in an EMIC, we aim to test the ability of two different hypotheses to explain this cooling: either a change in the atmospheric circulation as suggested by McGlone et al. (2010) and Shevenell et al. (2011), or an oceanic cooling induced here by a change in the local fwf. Today, there is no consensus on the melting of the West Antarctic ice sheet (WAIS) during the early Holocene (Bentley, 2010; Stone et al., 2003; Domack et al., 2005; Bianchi and Gersonde, 2004; Crespin et al., unpublished data; Pollard and DeConto, 2009; Peltier, 2004; Mackintosh et al., 2011) to justify this choice or to discard it a priori. Thus, the WAIS melting represents here a working hypothesis that allows us modifying in a relatively simple and straightforward way the oceanic temperature and the circulation in the Southern Ocean. We do not take into account any East Antarctic ice sheet (EAIS) melting. This choice is justified by arguments pointing out a larger stability of the EAIS compared to the WAIS (Bentley, 2010; Sidall et al., 2012) and weaker EAIS meltwater flux variability compared to that of the WAIS (Pollard and DeConto, 2009; Mackintosh et al., 2011).

To test these two hypotheses, different time-slice simulations are performed with the earth system model of intermediate complexity LOVECLIM (LOch-Vecode-Ecbilt-CLioagIsm Model; Goosse et al., 2010) for 10 and $8 \mathrm{ka}$. The baseline simulations take into account the different boundary conditions. New simulations include a data assimilation method. The complete description of the experimental design, including a brief description of the climate model, the experimental setup, the data assimilation technique and the proxies selected for data assimilation, is provided in Sect. 2. Section 3 investigates the impacts of a modification of atmospheric circulation and of WAIS fwf on SH surface climate and sea ice cover. Conclusions and perspectives are given in Sect. 4.

\section{Experimental design}

\subsection{Model description}

We have performed our experiments with the threedimensional Earth climate model of intermediate complexity LOVECLIM. The model configuration includes a representation of atmosphere, ocean, sea ice and land surface. Each model component is briefly described here. A comprehensive description of the model, as well as a description of the model performance for standard cases (present climate, last decade, last millennium and last glacial maximum), is available in Goosse et al. (2010). The atmospheric component of LOVECLIM is ECBILT (Opsteegh et al., 1998). It is a quasi-geostrophic spectral model with 3 vertical levels corresponding to an equivalent horizontal resolution of $5.6 \times 5.6^{\circ}$ latitude/longitude. ECBILT is coupled with the ocean/sea ice model CLIO (Goosse and Fichefet, 1999; Fichefet and Morales Maqueda, 1997). CLIO is a general circulation model with a horizontal resolution of $3 \times 3^{\circ}$ and a vertical resolution ranging from $10 \mathrm{~m}$ near surface to $500 \mathrm{~m}$ at $5500 \mathrm{~m}$ depth. LOVECLIM also contains the simple vegetation model VECODE (Brovkin et al., 2002) at the same resolution of the ECBILT model. Because LOVECLIM is much faster than many other three dimensional climate models, large ensembles of simulations can be carried out for data assimilation. 
All experiments are 400-yr-long equilibrium runs (or timeslices) with constant forcing. These experiments are driven by orbital forcing (Berger, 1978). Greenhouse gases concentrations are imposed from data of Flückiger et al. (2002). As no ice sheet model is coupled to LOVECLIM in the configuration selected here, ice sheet topography and fwf are prescribed accordingly to the data available at 10 and $8 \mathrm{ka}$. The ice sheet topography from the reconstruction of Peltier (2004) was adapted to LOVECLIM by Renssen et al. (2009) and the ice sheet does not evolve during the $400 \mathrm{yr}$ of time-slice simulations. For the Laurentide ice sheet melting, fwf from Licciardi et al. (1999) is imposed for the St Lawrence and Hudson River outlets. It amounts to $40 \mathrm{mSv}$ for both outlets at $10 \mathrm{ka}$ and to $10 \mathrm{mSv}$ and $70 \mathrm{mSv}$ at $8 \mathrm{ka}$, respectively. In the experiments considered here, we have not prescribed additional fwf that could represent other sources, such as the melting of the Greenland and Scandinavian ice sheets at $10 \mathrm{ka}$. For the Antarctic ice sheet fwf, we only consider a reference value for WAIS fwf prescribed at $50 \mathrm{mSv}$ for both time slices based on Pollard and DeConto (2009). Additional experiments are performed using different fwf in the Southern Ocean (Table 2), as discussed in Sect. 3. This fwf is applied in Amundsen, Bellingshausen and the west part of Weddell Seas. Melting of the East Antarctic ice sheet is neglected (Mackintosh et al., 2011).

\subsection{Assimilation method}

The data assimilation method used here is the particle filter with resampling (van Leeuwen et al., 2009). A complete description of the procedure and the implementation is given in Dubinkina et al. (2011) but a brief summary is provided here. First, an ensemble of 48 simulations, called "particles" or ensemble members, is initialized by adding a small noise to the atmospheric stream function of a single model state. Each particle is then propagated in time by the climate model. After one year, the likelihood of each particle is computed from the difference between the observed or reconstructed temperatures and the simulated ones. The particles are then resampled according to their likelihood, i.e., to their ability to reproduce the signal derived from the available records. The particles with low likelihood are stopped, while the particles with a high likelihood are copied a number of times proportional to their likelihood in order to keep the total number of particles constant throughout the period covered by the simulations, keeping the new weight of each particle equal to one. A small noise is again added to the atmospheric stream function of each copy to obtain different time developments for the following year. The entire procedure is repeated sequentially every year until the final year of calculation $(400 \mathrm{yr}$ here).

\subsection{Proxy data}

Temperature reconstructions used to constrain model results in the data assimilation experiments come from different archives. For marine and pollen records (Table 1, Fig. 1), the original calibration is retained and the data error is assumed to be $0.7^{\circ} \mathrm{C}$. For ice cores (Table 1, Fig. 1, the data are based on $\delta^{18} \mathrm{O}$ and $\delta \mathrm{D}$ measurements, scaled to temperature using the classical approach based on the spatial slope of $0.8 \% 0^{\circ} \mathrm{C}^{-1}$ and $6.34 \% 0^{\circ} \mathrm{C}^{-1}$ for $\delta^{18} \mathrm{O} / \mathrm{T}$ and $\delta \mathrm{D} / \mathrm{T}$, respectively (Masson-Delmotte et al., 2008). The uncertainty of temperature estimates remains difficult to fully quantify. Water stable isotope records in ice cores are affected by condensation temperature during precipitation events, but also by changes in ice sheet surface elevation (Siddall et al., 2012). While they are classically related to annual mean surface air temperature, these records are affected by precipitation intermittency or seasonality (Laepple et al., 2011), boundary layer dynamics affecting the relationship between surface and condensation temperature, wind erosion and by changes in moisture sources (Masson-Delmotte et al., 2011). These processes may produce a temporal isotope-temperature relationship, which can be lower than the spatial gradient (Sime et al., 2008). Using the spatial gradient may therefore lead to an underestimation of temperature changes. As uncertainties on central East Antarctic temperature anomalies were suggested to reach 20-30\% (Jouzel et al., 2003), we decided to attribute an uncertainty on 10 and $8 \mathrm{ka}$ anomalies of $0.3^{\circ} \mathrm{C}$. These error bars on marine $\left(0.7^{\circ} \mathrm{C}\right)$, pollen $\left(0.7^{\circ} \mathrm{C}\right)$ and ice core $\left(0.3^{\circ} \mathrm{C}\right)$ data are lower than the typical values given in the literature. This is a deliberate choice to strongly constrain the simulations with data assimilation on the Southern Ocean as well as on Antarctica. A reasonable increase of the errors would not change qualitatively our conclusions but could modulate the amplitude of the simulated changes (e.g., Goosse et al., 2012).

In the data assimilation experiments, it is necessary to compare model results and data through anomalies with respect to the preindustrial reference period, here covering years from 1.5 to $0.5 \mathrm{ka}$. As a consequence, proxy records which do not cover both this reference period and the study period (from 8.5 to $7.5 \mathrm{ka}$ for the time-slice at $8 \mathrm{ka}$ or from 10.5 to $9.5 \mathrm{ka}$ for the time-slice at $10 \mathrm{ka}$, respectively) with high enough temporal resolution (at least $300 \mathrm{yr}$ ) are excluded from our simulations with data assimilation. All the selected data are summarized in Table 1a. Some records rejected for data assimilation are kept for independent validation as well as recently released data (Mulvaney et al., 2012) that were not available to us at the time the simulations were launched (Table 1b). The location of each record is shown in Fig. 1. We have also excluded the records from Byrd, Siple Dome, Plateau Remote and Dominion Range ice cores. The first ones (Byrd and Siple Dome records) may be affected by ice flow dynamics and elevation changes (Sidall et al., 2012). 
Table 1. (a) Description of all the proxy records used in the data assimilation experiments. (b) Description of all the proxy records used for model validation. (c) Description of all qualitative proxy types used in the text. The classification of proxy records from the subtropical area or from the Southern Ocean (north of $66^{\circ} \mathrm{S}$ and south of subtropical front) depends on the type of climate dynamics suggested in the corresponding reference. By default, diatoms are marine diatoms.

\begin{tabular}{|c|c|c|c|c|}
\hline (a) Id & Name & Location & Proxy type & Reference \\
\hline 1 & Law Dome & Antarctica & $\delta^{18} \mathrm{O}$ & $\begin{array}{l}\text { Courtesy of T. van Ommen, A. Moy et al., } \\
\text { personal communication (2012) }\end{array}$ \\
\hline 2 & Vostok & Antarctica & $\delta^{18} \mathrm{O}$ & Vimeux et al. (1999) \\
\hline 3 & Taylor Dome & Antarctica & $\delta^{18} \mathrm{O}$ & Steig et al. (1998) \\
\hline 4 & Fuji Dome & Antarctica & $\delta^{18} \mathrm{O}$ & Watanabe et al. (2003) \\
\hline 5 & EDC & Antarctica & $\delta^{18} \mathrm{O}$ & Masson-Delmotte et al. (2004) \\
\hline 6 & KMS & Antarctica & $\delta \mathrm{D}$ & Nikolaiev et al. (1988) \\
\hline 7 & TALDICE & Antarctica & $\delta^{18} \mathrm{O}$ & Stenni et al. (2011) \\
\hline 8 & EDML & Antarctica & $\delta^{18} \mathrm{O}$ & EPICA Comm. Members (2006) \\
\hline 9 & MtHoney & Southern Ocean & Pollen & McGlone et al. (2010) \\
\hline 10 & TN057-17TC & Southern Ocean & Diatoms & Nielsen et al. (2004) \\
\hline 11 & MD03-2611 & Subtropical & Alkenone & Lamy et al. (2002) \\
\hline 12 & ODP1084B & Subtropical & $\mathrm{Mg} / \mathrm{Ca}$ & Farmer et al. (2005) \\
\hline 13 & ODP 1098 & Southern Ocean & $\mathrm{TEX}_{86}$ & Shevenell et al. (2011) \\
\hline (b) Id & Name & Location & Proxy type & Reference \\
\hline 20 & MD97-2121 & Subtropical & Alkenone & Pahnke and Sachs (2006) \\
\hline 21 & GIK17748-2 & Subtropical & Alkenone & Kim et al. (2002) \\
\hline 22 & IODP1089 & Subtropical & Radiolerian & Cortese et al. (2007) \\
\hline 23 & MD88-770 & Subtropical & Foraminifera & Salvignac (1998) \\
\hline 24 & MD97-2120 & Southern Ocean & Alkenone & Pahnke and Sachs (2006) \\
\hline 25 & IODP1233 & Southern Ocean & Alkenone & Kaiser et al. (2005) \\
\hline 26 & TNO57-13-PC4 & Southern Ocean & Diatoms & Hodell et al. (2001) \\
\hline 27 & MD97-2101 & Southern Ocean & Diatoms & Crosta et al. (2005) \\
\hline 28 & SO136-111 & Southern Ocean & Diatoms & Crosta et al. (2004) \\
\hline 29 & MD84-551 & Southern Ocean & Diatoms & Pichon (1985) \\
\hline 30 & James Ross Island & Southern Ocean & $\delta \mathrm{D}$ & Mulvaney et al. (2012) \\
\hline (c) Id & Name & Location & Proxy type & Reference \\
\hline 40 & MD03-2601 & Sea ice & Diatoms/TEX86 & Crosta et al. (2008), Denis et al. (2009), Kim et al. (2012) \\
\hline 41 & JPC24 & Sea ice & Diatoms & Denis et al. (2010), Barbara et al. (2010) \\
\hline 42 & Lake Figurnoye & Antarctica & Lake Diatoms & Verkulich et al. (2002) \\
\hline 43 & IODP1093/4 & Southern Ocean/sea ice & Diatoms & Bianchi and Gersonde (2004) \\
\hline
\end{tabular}

The last ones (Plateau Remote and Dominion Range) do not have sufficient resolution (Masson-Delmotte et al., 2000).

These conditions of data selection do not allow keeping any data near the Kerguelen Plateau, along South America, the east Pacific, the west Atlantic and West Antarctica. Therefore, the data assimilation system constrains the model over the Southern Ocean with only 3 records (West Antarctic Peninsula, east Atlantic and Tasmania/New Zealand areas).

\subsection{Simulation strategy}

Several 400-yr-long equilibrium runs with constant forcing are realized for 10 and $8 \mathrm{ka}$ with and without data assimilation. These simulations are initialized by the results from a long equilibrium run (with a duration of $3000 \mathrm{yr}$ ) with constant forcings for 10 and $8 \mathrm{ka}$, respectively. They all include an ensemble of 48 particles. The simulations without data assimilation, named respectively STD8 and STD10, provide reference climates against which the impact of data assimilation can be assessed. Hereafter, the simulated temperature refers to the mean state of the ensemble. Hereafter, the acronym STD corresponds to the difference between the time-slice simulations (STD8-STD10).

The control simulation used to compute the model anomalies and to compare them with proxy data anomalies in the data assimilation process, is based on a transient simulation carried out over the period 1-2000 CE (current era). For the period 1-850 CE, no volcanic forcing is applied and total solar irradiance and land use change are derived from a linear interpolation between 1 and the value in $850 \mathrm{CE}$ provided in the framework of Paleo Modelling Intercomparison Project Phase 3 (PMIP3, Schmidt et al., 2011). Afterward, all 
forcings come from the PMIP3 protocol. The description of these forcings is detailed in Crespin et al. (2013).

First, to test the influence of changes in atmospheric circulation (first hypothesis), we performed simulations with assimilation of atmospheric and sea surface temperature data for both 10 and $8 \mathrm{ka}$ (ATM10 and ATM8, Table 2). In these experiments, the atmospheric stream function is perturbed and the assimilation step (i.e. the selection of the ensemble members based on model-data comparison) is done each year. No modification of the fwf reference is applied in ATM8 and ATM10. When we discuss differences between these new simulations (ATM8-ATM10), the acronym ATM is used for simplicity.

The goal of the second group of experiments with data assimilation is to test the influence of changes in ocean temperatures. This is done by changing the fwf due to the WAIS melting between 10 and $8 \mathrm{ka}$. The "best guess" fwf for LOVECLIM is estimated using data assimilation. Here, the assimilation time step is $50 \mathrm{yr}$ (instead of $1 \mathrm{yr}$ in the previous experiments). Because the response time of the ocean is much longer than of the atmosphere, a longer period is thus required to estimate the effect of the perturbation. In these experiments, the ensemble members are produced by adding a small noise to the fwf (instead of perturbating the atmospheric stream function as done in the previous experiments). The perturbed fwf applied at time $t, \operatorname{FWF}(t)$, is derived from an autoregressive process such as

$\mathrm{FWF}(t)=\mathrm{FWF}(t-1)+0.5 \varepsilon_{\mathrm{FWF}}(t-1)+\varepsilon_{\mathrm{FWF}}(t)$,

where $\varepsilon_{\mathrm{FWF}}(t)$ is a Gaussian noise following the distribution $N\left(0, \sigma_{\mathrm{FWF}}\right) . \sigma_{\mathrm{FWF}}$ is equal to $30 \mathrm{mSv}$ in this study. This method allows extracting a fwf that provides the best agreement with the proxy records. This method is applied in simulations named varFWF8 and varFWF10.

Third, two simulations without data assimilation are then carried out with the fwf estimates derived from varFWF8 and varFWF10 for 8 and $10 \mathrm{ka}$, respectively. These experiments are named FWF8 and FWF10.

Finally, in order to combine the effects of changes in atmospheric circulation and of an increase of fwf, additional experiments are performed with an atmospheric circulation perturbation and an assimilation time step of $1 \mathrm{yr}$ as for ATM8 and ATM10, and the fwf derived from varFWF8 and varFWF10. These experiments for 8 and $10 \mathrm{ka}$ are named ATMFWF8 and ATMFWF10, respectively. This two-step procedure, required as the current version of the data assimilation method, is not adapted to handle processes characterized by very different timescales. All the simulations, their names, the type of perturbation and the amount of the fwf are described in Table 2. When we discuss the differences (FWF8FWF10) and (ATMFWF8-ATMFWF10), the acronyms FWF and ATMFWF are used for simplicity.
Table 2. Description of all the simulations through their name, the value of the WAIS fwf applied, the use of data assimilation (or not) and the target period $(8$ or $10 \mathrm{ka})$.

\begin{tabular}{llll}
\hline Name & $\begin{array}{l}\text { WAIS fwf } \\
(\mathrm{mSv})\end{array}$ & $\begin{array}{l}\text { Data } \\
\text { Assimilation }\end{array}$ & $\begin{array}{l}\text { Date of the } \\
\text { time-slice }\end{array}$ \\
\hline STD 8 & 50 & No & $8 \mathrm{ka}$ \\
STD 10 & 50 & No & $10 \mathrm{ka}$ \\
ATM 8 & 50 & Yes & $8 \mathrm{ka}$ \\
ATM 10 & 50 & Yes & $10 \mathrm{ka}$ \\
varFWF8 & Variable & Yes & $8 \mathrm{ka}$ \\
varFWF10 & Variable & Yes & $10 \mathrm{ka}$ \\
FWF 8 & 120 & No & $8 \mathrm{ka}$ \\
FWF 10 & 25 & No & $10 \mathrm{ka}$ \\
ATMFWF 8 & 120 & Yes & $8 \mathrm{ka}$ \\
ATMFWF 10 & 25 & Yes & $10 \mathrm{ka}$ \\
\hline
\end{tabular}

To compare model results with data, we use a mean absolute error (MAE) metrics:

$\mathrm{MAE}=\overline{\left|\Delta T_{\bmod }-\Delta T_{\mathrm{obs}}\right|}$,

where $\Delta T$ is the temperature differences between 8 and $10 \mathrm{ka} . \Delta T_{\text {obs }}\left(\Delta T_{\text {mod }}\right)$ corresponds to temperature difference observed (modelised) at one location. The overbar denotes an average over all the Antarctic or the Southern Ocean data locations.

\subsection{WAIS fresh water flux}

The Southern Hemisphere fwf amount and input locations are not well known. In contrast to the NH (Northern Hemisphere), where the fwf due to ice sheet melting is relatively well documented (Licciardi et al., 1999), there is no consensus between ice sheet modeling and marine $\delta^{18} \mathrm{O}$ records.

From ice sheet modelling, Pollard and DeConto (2009) diagnosed an amount of $50 \mathrm{mSv}$ for the WAIS melting during the early Holocene (10 to $6 \mathrm{ka}$ ). This flux is the one applied in STD simulations. Earlier ice sheet reconstruction (Peltier, 2004) showed a larger melting rate of the Antarctic ice sheet in a period $8 \mathrm{ka}$, compared to 6 and $10 \mathrm{ka}$ periods. Recent simulations of Mackintosh et al. (2011) exhibit a relatively constant melting rate between 11 and $7 \mathrm{ka}$, followed by a weaker melting of the Antarctic ice sheet. While these modeling studies converge on a decrease of the melting rate around $6 \mathrm{ka}$, they diverge on the evolution of melting rate between 10 and $7 \mathrm{ka}$. Differences between those studies could be explained by differences in forcing methods. All these studies are constrained by different and crude forcings for both atmospheric and oceanic components. The first study is driven by a stacked deep-sea core $\delta^{18} \mathrm{O}$ record for the oceanic forcing and by a parameterization depending from elevation, orbital configuration and sea level. The reconstruction from Peltier (2004) is constrained by sea level curve and isostasy. The last study is driven by the modern 
temperature and precipitation climatology adjusted to follow the Vostok ice core record and forced also by oceanic heat flux driven mainly by changes in far-field ocean temperatures represented by a benthic $\delta^{18} \mathrm{O}$ stack. Additionally, Pollard and DeConto (2009) show that the WAIS ice sheet could be very sensitive to these forcings, and particularly to the ocean heat fluxes.

For the WAIS, large regional differences are reported from glaciological studies. A gradual retreat of ice streams of Marie Byrd Land has been suggested (Stone et al., 2003). By contrast, a rapid retreat of the grounding line of the ice stream occupying the George VI Sound is documented around $9.5 \mathrm{ka}$, followed by stabilization of the ice stream (Bentley, 2010). On the other side of the Antarctic Peninsula, the Larsen B persisted during the Holocene until its recent collapse (Domack et al., 2005). These examples show that the early Holocene history of the WAIS is complex and not sufficiently documented to build a common scenario. Furthermore, the melting rate of an ice shelf is influenced by the bathymetry profile below the ice shelf (Schoof et al., 2007). This point shows that nonclimatic variables could also have a large impact on the location and the timing of ice shelf melting.

Marine observations from foraminifera and diatoms, which could be interpreted as indicators of the amount of fresh water release to the Southern Ocean (Bianchi and Gersonde, 2004), do not show drastic changes in the glacial meltwater inflow between 10 and $8 \mathrm{ka}$. In the south Atlantic $\left(50-53^{\circ} \mathrm{S}, 5^{\circ} \mathrm{E}\right)$, the $\delta^{18} \mathrm{O}$ measured in planktic foraminifers demonstrates a small trend toward lighter values between 9 and $7 \mathrm{ka}$ (Bianchi and Gersonde, 2004). Similarly, the $\delta^{18} \mathrm{O}$ measured in diatoms evidences a $1.5 \%$ o decrease over the course of the Holocene, with a small drop during the 10 to $8 \mathrm{ka}$ period (Hodell et al., 2001). In coastal areas, a $\delta^{18} \mathrm{O}$ diatom record from West Antarctic Peninsula presents a large drop between 10.5 and $8.9 \mathrm{ka}$ (Pike et al., 2013), while $\delta^{18} \mathrm{O}$ diatom records in East Antarctica depict a $500 \mathrm{yr}$ event of light values centered at $9.2 \mathrm{ka}$ (Crespin et al., unpublished data) or a small increase toward enriched values (Berg et al., 2010).

It is therefore difficult to faithfully assess changes in fwf due to WAIS melting between 10 and $8 \mathrm{ka}$ from the existing data. The uncertainties on timing and melting rate are, thus, large enough to justify the study, with an Earth climate model of intermediate complexity such as LOVECLIM, of how modifications of this fwf can affect the early Holocene SH high latitude climate, and which fwf amount leads to the best consistency between the simulated and reconstructed temperature patterns. We are fully aware that all the results are probably model dependent and subject to many limitations due to the model selected resolution, physics, forcings, the data assimilation method and the target data, as discussed in more details below.

\section{Results and discussion}

Running LOVECLIM without data assimilation (STD8 and STD10) does not reproduce the cooling observed at high southern latitudes between 10 to $8 \mathrm{ka}$ in both atmospheric and sea surface temperature. By contrast, the model simulates a warming between the two time-slices (Fig. 2a), especially south of the polar front (up to $0.5^{\circ} \mathrm{C}$ ). The comparison with proxy reconstruction available for these periods shows a relative high MAE of $1.01{ }^{\circ} \mathrm{C}$ (Antarctica) and $1.26^{\circ} \mathrm{C}$ (Southern Ocean) (Table 3). This warming is caused by an inflow of warmer North Atlantic deep water (NADW) in the Southern Ocean at $8 \mathrm{ka}$ compared to $10 \mathrm{ka}$. In both time-slices, the NH fwf is high enough to suppress the convection in the Labrador Sea. By contrast, the convection in Norwegian and Greenland Seas is active for both periods. As the Laurentide ice sheet is smaller at $8 \mathrm{ka}$ than at $10 \mathrm{ka}$, the North Atlantic surface temperature is warmer. As explained in Renssen et al. (2010), the NADW formed in the Greenland and Norwegian Seas is warmer, inducing a warming at high southern latitudes at $8 \mathrm{ka}$. As in Renssen et al. (2010), we call this processes, hereafter, an advective teleconnection.

The climate simulated in STD experiments is, thus, not consistent with data. This might be due to several processes such as low frequency internal variability of the system not well taken into account by the model, to inadequate model physics that do not allow a correct response to the forcing, or the realism of the model forcing itself.

Between ATM8 and ATM10, the changes in atmospheric circulation due to data assimilation imply a cooling over Antarctica and off Dronning Maud Land. The cooling simulated along coastal areas of the Bellingshausen Sea and off Adélie Land is not significant (Fig. 2b). In contrast with STD that displays very weak changes in atmospheric circulation, the surface temperature changes simulated by the LOVECLIM model in ATM is due to a weakening of the circumpolar trough, especially in the Ross Sea, Prydz Bay and Weddell Sea areas (Fig. 3b). The atmospheric circulation simulated in ATM8 restrains the inflow of warm air into the Antarctic area and limits also the outflow of cold air out of Antarctica. Consequently, this change in meridional atmospheric circulation leads to a cooling of the Antarctic continent. Even if the magnitude of the cooling (Fig. 2b) is weaker than in the reconstructions (Fig. 1), the simulated surface temperature field over Antarctica matches relatively well the proxy reconstructions (MAE is $0.45^{\circ} \mathrm{C}$ in ATM, Table 3). However, a warming is still simulated over the Southern Ocean, leading to larger errors (MAE of $1.04^{\circ} \mathrm{C}$, Table 3 ). This warming is slightly reduced compared to the STD experiments (error of $1.26^{\circ} \mathrm{C}$ in STD, Table 3), but cannot compensate for the upwelling of warmer CDW due to the advective teleconnection at $8 \mathrm{ka}$. To explain the observed cooling over Southern Ocean seen in the proxy-based temperature reconstructions at $8 \mathrm{ka}$, another mechanism has to be involved. 

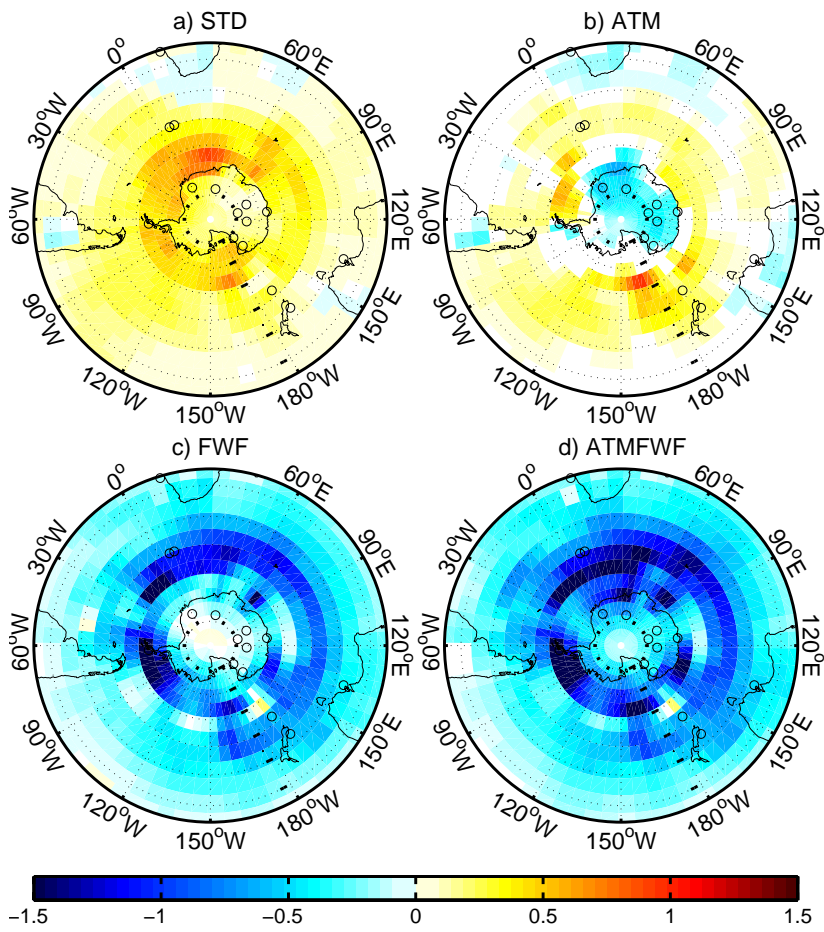

$-1.5$

$$
-1
$$$$
-0.5
$$

1.5

Fig. 2. Difference of the annual mean atmospheric surface temperature between 8 and $10 \mathrm{ka}$ ( $8 \mathrm{ka}$ minus $10 \mathrm{ka}$ ) for (a) STD, (b) ATM, (c) FWF, (d) ATMFWF. Colored areas correspond to differences significant at the $99 \%$ level according to a Student $t$ test.

Table 3. Mean absolute error (MAE) in ${ }^{\circ} \mathrm{C}$ of the various simulations (STD, ATM, FWF and ATMFWF) for Antarctic and the oceanic Southern Ocean temperatures. For each region and experiment, the MAE is computed by the average of the absolute value of the deviations between 8 minus $10 \mathrm{ka}$ anomalies from reconstructions and model at the same location. Records considered as Antarctic records or Southern Ocean records are described in Table $1 \mathrm{a}$ and $\mathrm{b}$.

\begin{tabular}{lrr}
\hline Experiments & Antarctica & Southern Ocean \\
\hline STD & 1.01 & 1.26 \\
ATM & 0.45 & 1.04 \\
FWF & 0.74 & 0.77 \\
ATMFWF & 0.38 & 0.66 \\
\hline
\end{tabular}

In the FWF experiments, we emulate the oceanic cooling by an increase of the fwf input. In this way, data assimilation experiment varFWF has been used to select the amount of fresh water release by the WAIS that best fits the surface temperature data at 10 and $8 \mathrm{ka}$ (Fig. 4). At $10 \mathrm{ka}$, the fwf reconstructed by data assimilation is systematically lower than $50 \mathrm{mSv}$ (variations between $10 \mathrm{mSv}$ and $50 \mathrm{mSv}$ ). The mean value is estimated to be $25 \mathrm{mSv}$ instead of $50 \mathrm{mSv}$ for the reference scenario used in STD10 (Fig. 4a). For the 8 ka period, the fwf estimates reach equilibrium after $100 \mathrm{yr}$. The selected scenario $(120 \mathrm{mSv})$ suggests a larger WAIS melting
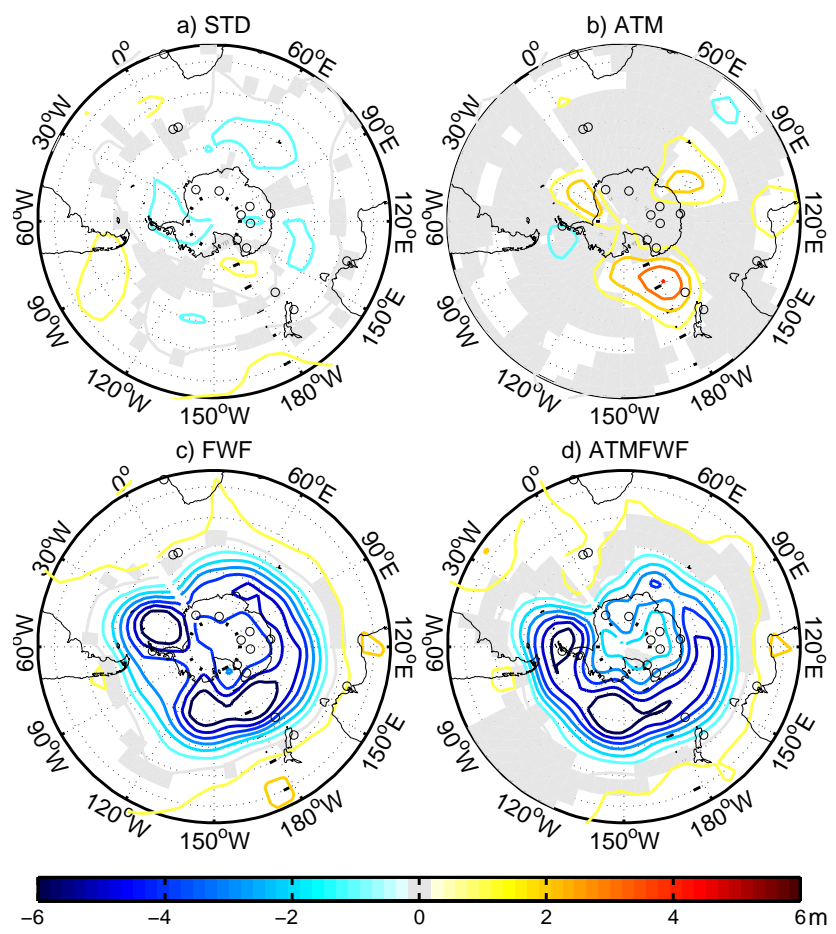

Fig. 3. Difference of annual geopotential heigh at $800 \mathrm{hpa}$ (in $\mathrm{m}$ ) between 8 and $10 \mathrm{ka}$ ( $8 \mathrm{ka}$ minus $10 \mathrm{ka}$ ). (a) STD, (b) ATM, (c) FWF, (d) ATMFWF. Grey areas correspond to nonsignificant differences (99\% Student $t$ test).

$(+140 \%)$ than the reference one (Fig. 4b). Additional experiments carried out with only assimilation of ice core data (not shown) bring out almost the same scenarios for both periods $(50 \mathrm{mSv}$ for $10 \mathrm{ka}$, and $110 \mathrm{mSv}$ for $8 \mathrm{ka})$. The WAIS fwf optimised from the simulations varFWF8 and varFWF10 represents our current "best guess" estimate. To explain the cooling in the southern high latitudes during the transition between 10 to $8 \mathrm{ka}$, the data assimilation method suggests $\mathrm{a} \sim 100 \mathrm{mSv}$ increase of WAIS melting from 10 to $8 \mathrm{ka}$. These fwf estimates are applied in the simulation FWF8 and FWF10. An increase of fwf during this cold event could be counter-intuitive. However, melting of the ice sheet is not a simple direct response of the surface forcing and the ice sheet responds slowly to climate change (Bentley, 2010). Thus, a long lag could occur between the warm period observed at $10 \mathrm{ka}$ and the peak melting of the ice sheets. In addition, ocean processes linked to a release of fresh water lead to a warming of subsurface water masses (below $100 \mathrm{~m}$ ) south of $60^{\circ} \mathrm{S}$ (Swingedouw et al., 2009). A similar subsurface warming has been simulated in northern high latitudes during large melting events (Flückiger et al., 2006). This could create a positive feedback by increasing melting of the ice shelves. Therefore, due to nonlinear ice sheet and oceanic feedbacks, a larger fwf melting during a cold event cannot be discarded. Furthermore, as summarized in Section 2.5, no observations can be used to support or refute the magnitude and sign of 

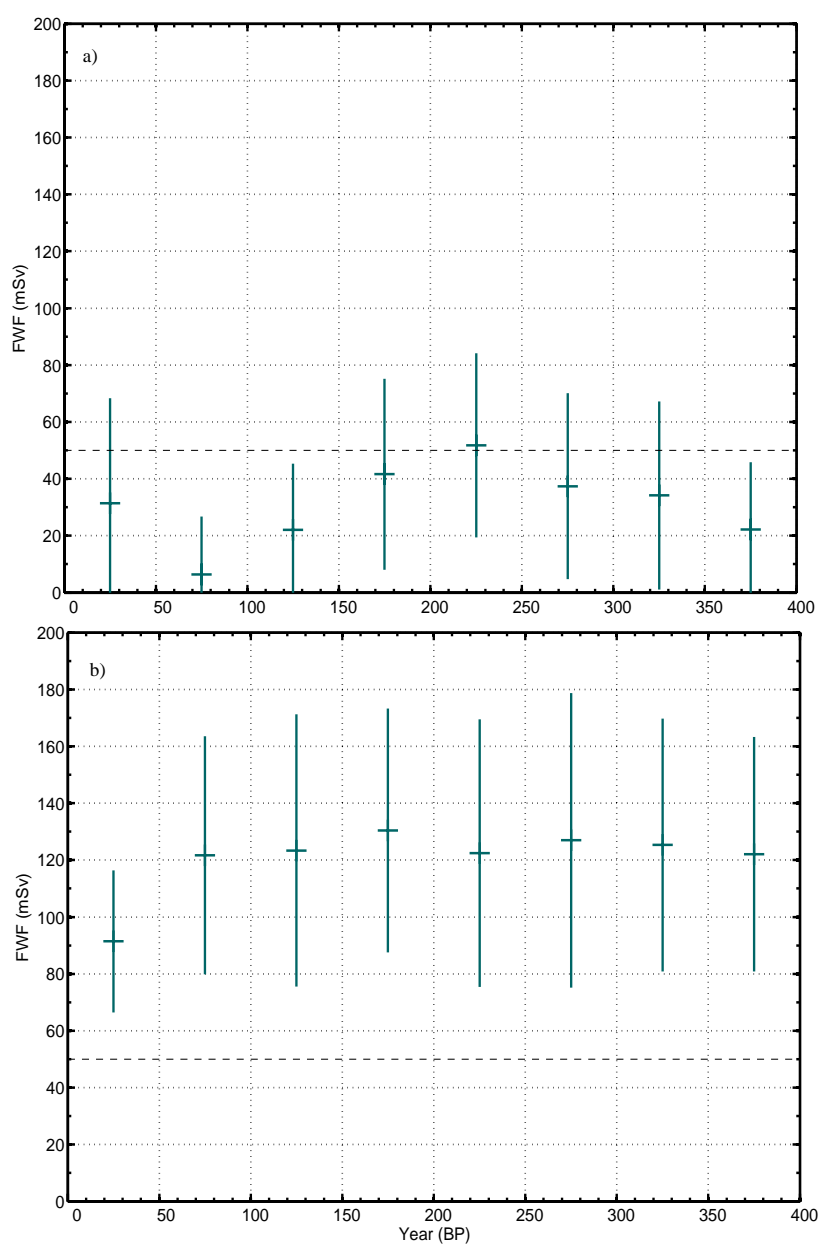

Fig. 4. Reconstruction of fwf based on data assimilation for $10 \mathrm{ka}$ (varFWF10 simulation) (a) and $8 \mathrm{ka}$ (varFWF8 simulation) (b). For each time step $(50 \mathrm{yr})$, the green cross is the mean value and green bar is the standard deviation. The $\mathrm{x}$-axis is the time since the beginning of the experiments. The dashed line is the reference value in 8 and $10 \mathrm{ka}$.

these changes. We, therefore, consider our results as a rough, first order estimate of fwf amounts (which could be model dependent) but not as a precise fwf reconstructions.

The FWF simulations depict a large cooling over most of the Southern Ocean from 10 to $8 \mathrm{ka}$, up to $-2{ }^{\circ} \mathrm{C}$ between STF and ASF. However, this only produces a slight Antarctic cooling (Fig. 2c). The obtained surface temperature pattern matches well the Southern Ocean proxy, leading to a MAE of $0.77^{\circ} \mathrm{C}$, which is better than the one observed in ATM and STD (Table 3). However, over the interior Antarctica, the ice core data suggest a much larger cooling than the one simulated in FWF experiments (MAE of $0.74^{\circ} \mathrm{C}$ ). A consequence of this large Southern Ocean cooling is a deepening of the circumpolar trough and an increase of the SWW $(+6 \%)$ (Fig. 3c). This strengthening of the westerlies (below $50^{\circ} \mathrm{S}$ ) at $8 \mathrm{ka}$ fits the reconstruction of SWW strength performed by
McGlone et al. (2010). However, over the Antarctic Peninsula, Shevenell et al. (2011) suggest a decrease of the SWW strength, which is not simulated in FWF.

The ocean and the atmosphere circulation changes have, thus, complementary effects on the surface temperature. The first one leads to a relatively large cooling over the Southern Ocean that is absent in the ATM experiments, and the second one leads to large cooling over the Antarctic continent. Therefore, to decrease both Southern Ocean and Antarctic continent surface temperature as shown in the observations (Fig. 1), one solution is to associate the method used for the ATM simulations with the fwf applied in FWF simulations. When both ATM and FWF are combined (in ATMFWF), a large cooling is produced over the SO (about $-1.6{ }^{\circ} \mathrm{C}$ ) together with a larger cooling over the Antarctic continent (about $-0.6{ }^{\circ} \mathrm{C}$ ) compared to STD. This cooling is also larger in Antarctica than the one simulated in ATM alone as shown in Fig. 2d during the transition from 10 to $8 \mathrm{ka}$. The corresponding minimum errors are $0.38^{\circ} \mathrm{C}$ for the Antarctic proxy data and $0.66^{\circ} \mathrm{C}$ for the Southern Ocean data (Table 3). The comparison of the different panels in Fig. 3 highlights that the response of the atmospheric dynamics to the data assimilation in the ATMFWF is roughly the sum of the changes seen in ATM and in FWF.

Data assimilation in ATM, FWF and ATMFWF does not only modify the annual mean state but also the seasonal cycle at all southern latitudes (Fig. 5). In the reference simulation, in central Antarctica (south of $75^{\circ} \mathrm{S}$ ), insolation changes between 10 and $8 \mathrm{ka}$ induce a winter cooling (from March to October) and a summer warming (from November to February), with a lag of one month as noticed in previous studies (Crucifix et al., 2002; Renssen et al., 2005). For oceanic regions (between $75^{\circ} \mathrm{S}$ to $55^{\circ} \mathrm{S}$ ), the $8 \mathrm{ka}$ time-slice is warmer than the $10 \mathrm{ka}$ time-slice during the entire year. The seasonal timing of the largest warming simulated in STD depends on the latitude. The largest warming occurs from November to January at $75^{\circ} \mathrm{S}$ and from July to August at $55^{\circ} \mathrm{S}$ (Fig. 5).

In FWF (and ATMFWF), the stratification of the surface ocean layer is stronger due to the larger release of fresh water at $8 \mathrm{ka}$, inducing a reduced vertical transport of heat. In FWF, over Antarctica, the atmosphere is cooled in winter by $-0.3^{\circ} \mathrm{C}$. During summertime (November to February), a weak warming is simulated (about $0.6^{\circ} \mathrm{C}$ ) between 10 and $8 \mathrm{ka}$. This feature is very similar to the one depicted in STD. By contrast, over the ocean (north of $70^{\circ} \mathrm{S}$ ), the surface air is cooled during almost the entire year in FWF. The season characterized by the largest vertical heat exchanges in the ocean in the STD simulation (May to September) is now simulated to be the coldest period in FWF (more than $1.5^{\circ} \mathrm{C}$ cooling) (Fig. 5).

In ATM (and ATMFWF), the atmospheric circulation reconstruction induces an enhanced seasonal cycle over the Antarctic continent, with similar summer and cooler winter compared to STD and FWF, respectively. Compared to STD and FWF, the change of atmospheric circulation obtained 

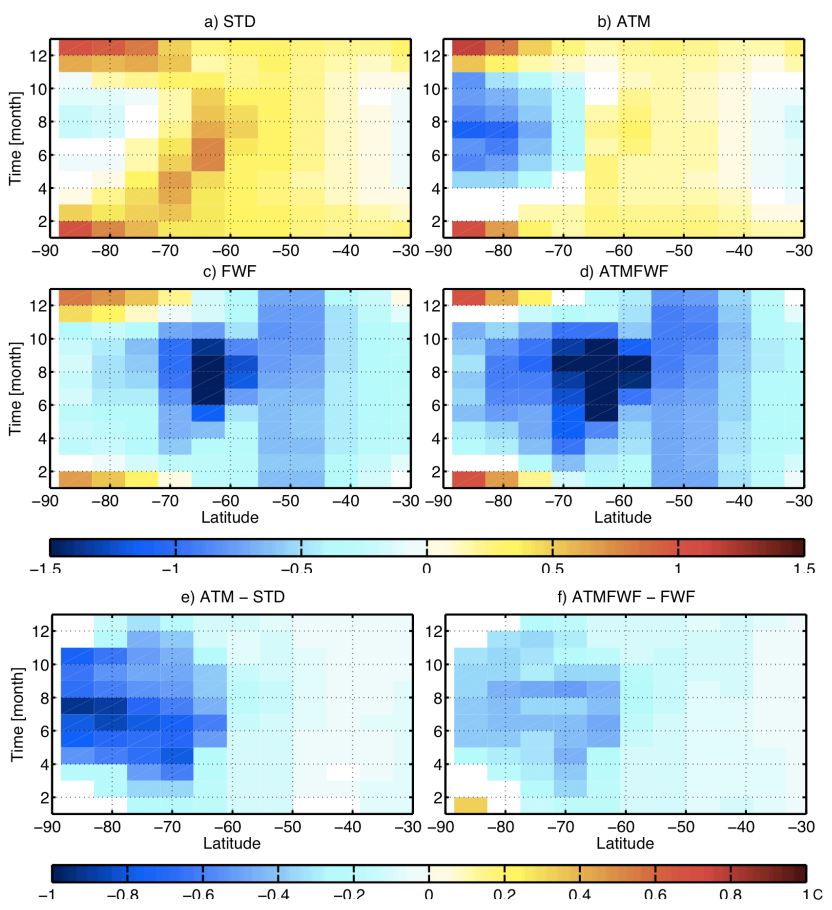

Fig. 5. Zonal mean temperature differences in ${ }^{\circ} \mathrm{C}$ between 8 and $10 \mathrm{ka}$ (8 ka minus $10 \mathrm{ka}$ ) for STD (a), ATM (b), FWF (c), ATMFWF (d). The difference between the data presented in panels (b) and (a) (d and c) is plotted on panel (e) (and f). Labels on the y-axis correspond to the beginning of the month. Colored areas correspond to differences significant at the $99 \%$ level according to a Student $t$ test. Note the different color bar for upper panels (a, b, c and d) and lower panels (e and $\mathbf{f}$ ).

by data assimilation and its impact on surface temperature is almost the same in ATM and FWFATM. From 10 to $8 \mathrm{ka}$, the atmospheric circulation changes constrained by surface temperature data induce a cooling of $-0.5(-0.3){ }^{\circ} \mathrm{C}$ over Antarctica during winter in ATM (ATMFWF) and -0.2 $(-0.1)^{\circ} \mathrm{C}$ over the Southern Ocean during all the year, compared to the transition in STD (FWF) (Fig. 5e, f).

Between $55^{\circ} \mathrm{S}$ and $40^{\circ} \mathrm{S}$, the seasonal and interannual variabilities of the surface temperature in the ACC are weak in STD, ATM, FWF and ATMFWF. Modifications of fwf or of the atmospheric circulation only alter the annual mean temperature without changing the amplitude of the seasonal cycle, only the annual temperature is modified.

The changes in surface air temperature due to modifications in atmospheric circulation or due to the cooling of oceanic surface temperatures are associated with a decrease (for both simulations with reference fwf, ATM and STD) and with an increase (for both simulations with modified fwf, FWF and ATMFWF) in sea ice concentration and sea ice duration (Fig. 6), the two variables for which proxy information is available. Reconstructions display an increase of sea ice duration from 10 to $8 \mathrm{ka}$ off the East Antarctic coast (Crosta et al., 2008; Denis et al., 2009; Verkulich et al., 2002) and
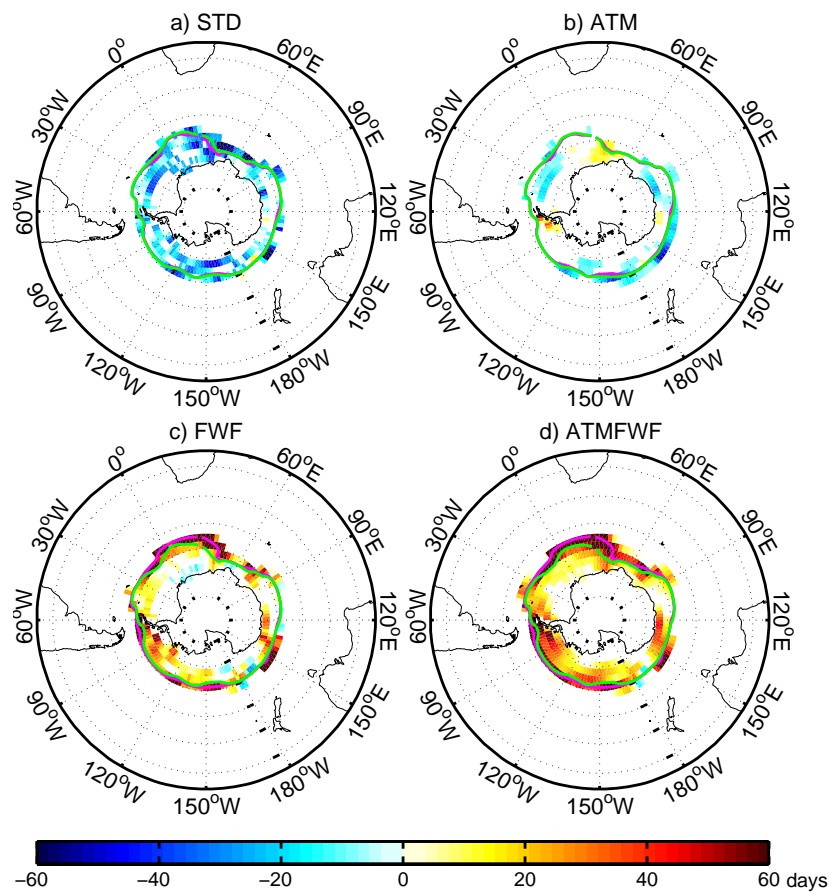

Fig. 6. Difference of sea ice duration between 8 and $10 \mathrm{ka}(8 \mathrm{ka}$ minus $10 \mathrm{ka}$ ) expressed in days for (a) STD, (b) ATM, (c) FWF (d) ATMFWF. Pink (green) lines show the sea ice extent during September at $8 \mathrm{ka}(10 \mathrm{ka})$. Colored areas correspond to differences significant at the $99 \%$ level according to a Student $t$ test.

a congruent northward migration of the sea-ice front from $\sim 55^{\circ} \mathrm{S}$ to $\sim 53^{\circ} \mathrm{S}$ in the Antarctic Atlantic (Bianchi and Gersonde, 2004; Nielsen et al., 2004).

In each simulation driven by surface temperature data assimilation, sea ice is present all year long in the southern part of Weddell and Ross seas. Consequently, no change is visible in sea ice duration there. The seasonal sea ice cover has different behavior if a cooling and a freshening of the oceanic surface is applied or not. In the STD, a decrease of sea ice duration by 10 days is simulated together with a lower maximum and minimum sea ice extent $\left(-0.5\right.$ million $\left.\mathrm{km}^{2}\right)$ (Fig. 6a). In the ATM simulation, the atmospheric circulation selected by the particle filter leads to an increase of sea ice duration off the west coast of the Antarctic Peninsula, Dronning Maud Land and Wilkes Land (Fig. 6b). This is in agreement with the simulated temperature patterns (Fig. 2b, d). In FWF and ATMFWF simulations, the cooling and freshening of ocean surface from 10 to $8 \mathrm{ka}$ conduct to an increase of sea ice duration by two months, an increase of winter sea ice extent by 2.5 million $\mathrm{km}^{2}$ and a northward migration of the sea-ice front in the Atlantic sector (Fig. 6c, d). However, in some grid points close to Dronning Maud Land, sea ice cover duration is reduced in FWF (Fig. 6c). This is due to warmer summer conditions (not shown here) and advection of warmer air mass, coming from the north, in this area. 
The sea ice simulated in FWF and ATMFWF is thus in good qualitative agreement with published proxy records. This suggests that sea ice changes are mainly driven by the oceanic cooling (second hypothesis) rather than by modifications of the atmospheric circulation (first hypothesis) during this period.

\section{Conclusions}

We have presented simulations performed with an intermediate complexity climate model, including experiments with data assimilation, to study the mechanisms responsible for the reconstructed southern high latitude cooling from 10 to $8 \mathrm{ka}$. We have tested two hypotheses, without taking into account other factors such as changes in the Antarctic ice sheet topography, or changes in ice shelves. Due to limitations in the data assimilation method, we evaluated their contributions in separate experiments. The good agreement between our final set of simulations (ATMFWF) and proxy data is encouraging and provides a consistent picture of climate change from 10 to $8 \mathrm{ka}$, for the continent and the Southern Ocean. Our study suggests the following results:

- Interhemispheric oceanic teleconnections (active in both time-slices) and warmer NH high latitude climate at $8 \mathrm{ka}$, lead to warmer CDW and warmer surface temperatures in the Southern Ocean and over Antarctica at $8 \mathrm{ka}$ compared to $10 \mathrm{ka}$. This means that the standard model configuration cannot simulate the observed cooling at SH high latitudes (with the exception of winter changes).

- Our data assimilation experiments show that the cooling over the Antarctic continent can be explained by a change in the atmospheric circulation and a modification of the meridional heat transport in the coastal areas. The Southern Ocean cooling is mainly driven by an increase of the fresh water release from the WAIS $(+100 \mathrm{mSv})$. Combination of these two processes gives the best comparison between model and proxy data (in term of MAE).

- The consequences of the oceanic cooling (due to enhanced WAIS fresh water release) on sea ice are compatible with the increase of the simulated sea ice duration observed in the coastal region of East Antarctica and in the Atlantic sector.

This study also presents a way to optimise a key unknown parameter (fwf in our case) to obtain a state compatible with proxy records and constrained by model physics. Nevertheless, the uncertainties on such reconstructions are directly related to the uncertainties on the climate model, on the method, and on data availability. The climate model LOVECLIM used in this study is a model with a coarse resolution and simplified physics. The results may be somehow different using a more sophisticated climate model. For example, it has been reported that the simulated impacts of Laurentide melting on oceanic water masses and Northern Hemisphere climate are significantly different in a coarse resolution model and in a high-resolution model (Spence et al., 2012), potentially affecting the model response in the Southern Ocean.

Uncertainties on the location and magnitude of the fwf forcing due to ice sheet melting in Northern Hemisphere remain large. Licciardi et al. (1999) show that the total input into the Arctic Ocean is about $11 \mathrm{mSv}$ at $10 \mathrm{ka}$, which represents $12 \%$ of the total water injected at $10 \mathrm{ka}$ in STD. Clark et al. (2012) report large changes of the Scandinavian ice sheet area between 11 and $10 \mathrm{ka}$. These sources of melt water in the Northern Hemisphere, which are not incorporated in our set of simulations could further modulate the intensity of bottom water formation in the Norwegian and Greenland seas (Bakker et al., 2012) and affect interhemispheric teleconnections mechanisms (bi-polar seesaw and advective teleconnection). Northern Hemisphere data assimilation may help to constrain those inputs as well as the characteristics of deep water formed in the North Atlantic and, thus, on CDW and the Southern Ocean surface temperature. In our current experimental setup, we cannot modify the the characterisitcs of the CDW at $8 \mathrm{ka}$ compared to $10 \mathrm{ka}$ due to this lack of data assimilation in the $\mathrm{NH}$.

There are also caveats intrinsic to our assimilation method. In the ensemble generation, if we perturb variables related to processes with different timescales, as for example the stream function (1 yr) and the fwf in the Southern Ocean (50 yr), the model, and thus the behaviour of the particle filter, will only be affected by the process that has a timescale similar to the assimilation time step. Consequently, the procedure has to be applied in two separate steps and does not take into account adequately all the interactions between various processes.

Finally, the proxies used cover only a small fraction of the high latitudes of the Southern Hemisphere. Furthermore, they are indirectly related to the freshwater flux to the Southern Ocean. Our experiments suggest that the cooling there, at $8 \mathrm{ka}$, is a strong feature of the system. We have shown that this can be achieved through an enhanced freshwater flux but additional reconstructions of surface temperature or of variables directly linked with fwf are required to confirm this hypothesis. 
Acknowledgements. We acknowledge D. Roche for making available the ice sheet forcing data for the LOVECLIM model. H. Goosse is Senior Research Associate with the Fonds National de la Recherche Scientifique (F.R.S. - FNRS-Belgium). P. Mathiot is a Postdoctoral researcher with F.R.S. - FNRS-Belgium. This work has been performed in the framework of the ESF HOLOCLIP project (a joint research project of the European Science Foundation PolarCLIMATE program, is funded by national contributions from Italy, France, Germany, Spain, Netherlands, Belgium and the United Kingdom), by the Belgian Federal Science Policy Office (Research Program on Science for a Sustainable Development) and is also supported by F.R.S. - FNRS. The research leading to these results has received funding from the European Union's Seventh Framework programme (FP7/2007-2013) under grant agreement no. 243908, "Past4Future: Climate change - Learning from the past climate". Computational resources have been provided by the supercomputing facilities of the Université catholique de Louvain (CISM/UCL) and the Consortium des Equipements de Calcul Intensif en Fédération Wallonie Bruxelles (CECI) funded by FRS-FNRS. This is HOLOCLIP contribution 16 and Past4Future contribution 40. The authors acknowledge the very constructive and precise comments of two anonymous reviewers.

Edited by: E. Zorita

\section{References}

Bakker, P., Van Meerbeeck, C. J., and Renssen, H.: Sensitivity of the North Atlantic climate to Greenland Ice Sheet melting during the Last Interglacial, Clim. Past, 8, 995-1009, doi:10.5194/cp-8995-2012, 2012.

Barbara, L., Crosta, X., Massé, G., and Ther, O.: Deglacial environments in eastern Prydz Bay, East Antarctica, Quaternary Sci. Rev., 29, 2731-2740, 2010.

Barrow, T. T., Lehman, S. J., Fifield, L. K., and De Deckker, P.: Absence of cooling in New Zealand and the adjacent ocean during the younger dryaschronozone, Science, 318, 86-89, 2007.

Bentley, M. J.: The Antarctic paleo record and its role in improving predictions of future Antarctic Ice Sheet change, J. Quat. Sci., 25, 5-18, 2010.

Berg, S., Wagner, B., Cremer, H., Leng, M. J., and Melles, M.: Late Quaternary environmental and climate history of Rauer Group, East Antarctica, Palaeogeogr. Palaeocl., 297, 201-213, 2010.

Berger, A. L.: Long-term variations of daily insolation and Quaternary climatic changes, J. Atmos. Sci., 35, 2363-2367, 1978.

Bianchi, C. and Gersonde, R.: Climate evolution at the last deglaciation: the role of the Southern Ocean, Earth Planet. Sc. Lett., 228, 407-424, 2004.

Brovkin, V., Bendtsen, J., Claussen, M., Ganopolski, A., Kubatzki, C., Petoukhov, V., and Andreev, A.: Carbon cycle, vegetation and climate dynamics in the Holocene: experiments with the CLIMBER-2 model, Global Biogeochem. Cy., 16, 1139, doi:10.1029/2001GB001662, 2002.

Capron, E., Landais, A., Chappellaz, J., Schilt, A., Buiron, D., Dahl-Jensen, D., Johnsen, S. J., Jouzel, J., Lemieux-Dudon, B., Loulergue, L., Leuenberger, M., Masson-Delmotte, V., Meyer, H., Oerter, H., and Stenni, B.: Millennial and sub-millennial scale climatic variations recorded in polar ice cores over the last glacial period, Clim. Past, 6, 345-365, doi:10.5194/cp-6-3452010, 2010.

Clark, P. U., Shakun, J. D., Baker, P. A., Bartlein Simon Brewer, P. J., Brook, E., Carlson, A. E., Cheng, H., Kaufman, D. S., Liu, Z., Marchitto, T. M., Mix, A. C., Morrill, C., Otto-Bliesner, B. L., Pahnke, K., Russell, J. M., Whitlock, C., Adkins, J. F., Blois, J. L., Clark, J., Colman, S. M., Curry, W. B., Flower, B. P., He, F., Johnson, T. C., Lynch-Stieglitz, J., Markgraf, V., McManus, J., Mitrovica, J. X., Moreno, P. I., and Williams, J. W. : Global climate evolution during the last deglaciation, P. Natl. Acad. Sci., 109, E1134-E1142, 2012.

Cook, E. R., Buckley, B. M., D’Arrigo, R. D., and Peterson, M. J.: Warm-season temperatures since $1600 \mathrm{BC}$ reconstructed from Tasmanian tree rings and their relationship to large-scale sea surface temperature anomalies, Clim. Dynam., 16, 79-91, 2000.

Cook, E. R., Buckley, B. M., Palmer, J. G., Fenwick, P., Peterson, M. J., Boswijk, G., and Fowler, A.: Millennia-long tree-ring records from Tasmania and New Zealand: a basis for modelling climate variability and forcing, past, present and future, J. Quat. Sci., 21, 689-699, 2006.

Cortese, G., Abelmann, A., and Gersonde, R.: The last five glacialinterglacial transitions: A high-resolution 450,000-year record from the subantarctic Atlantic, Paleoceanography, 22, PA4203, doi:10.1029/2007PA001457, 2007.

Crespin, E., Goosse, H., Fichefet, T., Mairesse, A., Sallaz-Damaz, Y.: Arctic climate over the past millennium: annual and seasonal responses to external forcings, Holocene, 23, 319-327, 2013.

Crosta, X., Sturm, A., Armand, L., and Pichon, J.-J.: Late Quaternary sea ice history in the Indian sector of the Southern Ocean as recorded by diatom assemblages, Mar. Micropaleontol., 50, 209-223, doi:10.1016/S0377-8398(03)00072-0, 2004.

Crosta, X., Crespin, J., Billy, I., and Ther, O.: Major factors controlling Holocene $\delta^{13} \mathrm{C}_{\text {org }}$ changes in a seasonal sea ice environment, Adélie Land, East Antarctica, Global Biogeochem. Cy., 19, GB4029, doi:10.1016/S0377-8398(03)00072-0, 2005.

Crosta, X., Denis, D., and Ther, O.: Sea ice seasonality during the Holocene, Ade'lie Land, East Antarctica, Mar. Micropaleontol., 66, 222-232, doi:10.1016/j.marmicro.2007.10.001, 2008.

Crowley, T. J.: North Atlantic Deep Water cools the Southern Hemisphere, Paleoceanography, 7, 489-497, 1992.

Crucifix, M., Loutre, M. F., Tulkens, P., Fichefet, T., and Berger, A.: Climate evolution during the Holocene: a study with an Earth system model of intermediate complexity, Clim. Dynam., 19, 4360, 2002.

Denis, D., Crosta, X., Schmidt, S., Carson, D., Ganeshram, R., Renssen, H., Bout-Roumazeilles, V., Zaragosi, S., Martin, B., Cremer, M., and Giraudeau, J.: Holocene glacier and deep water dynamics, Adélie Land region, East Antarctica, Quaternary Sci. Rev., 28, 1291-1303, 2009.

Denis, D., Crosta, X., Barbara, L., Masse, G., Renssen, H., Ther, O., and Giraudeau, J.: Sea ice and wind variability during the Holocene in East Antarctica: insight on middle-high latitude coupling, Quaternary Sci. Rev., 29, 3709-3719, 2010.

Domack, E., Duran, D., Leventer, A., Ishman, S., Doane, S., McCallum, S., Amblas, D., Ring, J., Gilbert, R., and Prentice, M.: Stability of the Larsen B ice shelf on the Antarctic Peninsula during the Holocene epoch., Nature, 436, 681-684, 2005.

Dubinkina, S., Goosse, H., Damas-Sallaz, Y., Crespin, E., and Crucifix, M.: Testing a particle filter to reconstruct climate changes 
over the past centuries, Int. J. Bifurcat. Chaos, 21, 3611-3618, 2011.

EPICA-community-members: One-to-one coupling of glacial climate variability in Greenland and Antarctica, Nature, 444, 195198, 2006.

Farmer, E. C., deMenocal, P. B., and Marchitto, T. M.: Holocene and deglacial ocean temperature variability in the Benguela upwelling region: implications for law-latitude atmospheric circulation, Paleoceanography, 20, PA2018, doi:10.1029/2004PA001049, 2005.

Fichefet, T. and Morales Maqueda, M. A.: Sensitivity of a global sea ice model to the treatment of ice thermodynamics and dynamics, J. Geophys. Res., 102, 12609-12646, 1997.

Fletcher, M.-S. and Moreno, P. I.: Have the Southern Westerlies changed in a zonally symmetric manner over the last 14,000 years? A hemisphere-wide take on a controversial problem, Quaternaly Int., 253, 32-46, 2012.

Flückiger, J., Monnin, E., Stauffer, B., Schwander, J., Stocker, T. F., Chappellaz, J., Raynaud, D., and Barnola, J.-M.: High resolution Holocene $\mathrm{N}_{2} \mathrm{O}$ ice core record and its relationship with $\mathrm{CH}_{4}$ and $\mathrm{CO}_{2}$, Global Biogeochem. Cy., 16, 1010, doi:10.1029/2001GB001417, 2002.

Goosse, H. and Fichefet, T.: Importance of ice-ocean interactions for the global ocean circulation: a model study, J. Geophys. Res., 104, 23337-23355, 1999.

Goosse, H., Lefebvre, W., de Montety, A., Crespin, E., and Orsi, A. H.: Consistent past half-century trends in the atmosphere, the sea ice and the ocean at high southern latitudes, Clim. Dynam., 33, 999-1016, 2009.

Goosse, H., Brovkin, V., Fichefet, T., Haarsma, R., Huybrechts, P., Jongma, J., Mouchet, A., Selten, F., Barriat, P.-Y., Campin, J.M., Deleersnijder, E., Driesschaert, E., Goelzer, H., Janssens, I., Loutre, M.-F., Morales Maqueda, M. A., Opsteegh, T., Mathieu, P.-P., Munhoven, G., Pettersson, E. J., Renssen, H., Roche, D. M., Schaeffer, M., Tartinville, B., Timmermann, A., and Weber, S. L.: Description of the Earth system model of intermediate complexity LOVECLIM version 1.2, Geosci. Model Dev., 3, 603-633, doi:10.5194/gmd-3-603-2010, 2010.

Goosse, H., Crespin, E., Dubinkina, S., Loutre, M. F., Mann, M. E., Renssen, H., Sallaz-Damaz, Y., and Shindell, D.: The role of forcing and internal dynamics in explaining the "Medieval Climate Anomaly", Clim. Dynam., 39, 2847-2866, 2012.

Hodell, D. A., Kanfoush, S. L., Shemesh, A., Crosta, X., Charles, C. D., and Guilderson, T. P.: Abrupt cooling of Antarctic surface waters and sea ice expansion in the South Atlantic Sector of the Southern Ocean at 5000 cal yr B.P., Quaternary Res., 56, 191198, 2001.

Holden, P. B., Edwards, N. R., Wolff, E. W., Lang, N. J., Singarayer, J. S., Valdes, P. J., and Stocker, T. F.: Interhemispheric coupling, the West Antarctic Ice Sheet and warm Antarctic interglacials, Clim. Past, 6, 431-443, doi:10.5194/cp-6-431-2010, 2010.

Jouzel, J., Vimeux, F., Caillon, N., Delaygue, G., Hoffmann, G., Masson-Delmotte, V., and Parrenin, F.: Magnitude of the isotopetemperature scaling for interpretation of central Antarctic ice cores, J. Geophys. Res., 108, 1029-1046, 2003.

Kaiser, J., Lamy, F., and Hebbeln, D.: A 70-kyr sea surface temperature record off southern Chile (Ocean Drilling Program Site 1233), Paleoceanography, 20, PA2009, doi:10.1029/2005PA001146, 2005.
Katsuki, K., Ikehara, M., Yokoyama, Y., Yamane, M., and Khim, B.K.: Holocene migration of oceanic front systems over the Conrad Rise in the Indian Sector of the Southern Ocean, J. Quat. Sci., 27, 203-210, 2012.

Kim, J. H., Schneider, R. R., Hebbeln, D., Muller, P. J., and Wefer, G.: Last deglacial sea-surface temperature evolution in the Southeast Pacific compared to climate changes on the South American continent, Quaternary Sci. Rev., 21, 2085-2097, 2002.

Kim, J. H., Schouten, S., Hopmans, E. C., Donner, B., and Sinninghe Damsté, J. S.: Global sediment core-top calibration of the TEX86 paleothermometer in the ocean, Geochim. Cosmochim. Ac., 72, 1154-1173, 2008.

Kim, J.-H., Crosta, X., Willmott, V., Renssen, H., Bonnin, J., Helmke, P., Schouten, S., and Sinninghe Damste, J. S.: Holocene subsurface temperature variability in the eastern Antarctic continental margin, Geophys. Res. Lett., 39, L06705, doi:10.1029/2012GL051157, 2012.

Lamy, F., Ruhlemann, C., Hebbeln, D., and Wefer, G.: High- and low-latitude climate control on the position of the southern PeruChile Current during the Holocene, Paleoceanography, 17, 16.116.10 doi:10.1029/2001PA000727, 2002.

Laepple, T., Werner, M., and Lohman, G.: Antarctic accumulation seasonality, Nature, 479, E2-E4, doi:10.1038/nature10614, 2011.

Licciardi, J. M., Teller, J. T., and Clark, P. U.: Freshwater Routing by the Laurentide Ice Sheet During the last Deglaciation, Mechanism of global Climate Change at Millennial Time Scales, Geophys. Monogr., 112, 177-201, 1999.

Mackintosh, A., Golledge, N., Domack, E., Dunbar, R., Leventer, A., White, D., Pollard, D., DeConto, R., Fink, D., Zwartz, D., Gore, D., and Lavoie, C.: Retreat of the East Antarctic ice sheet during the last glacial termination, Nature Geoscience, Nat. Geosci., 4, 195-202, doi:10.1038/NGEO1061, 2011.

Masson-Delmotte, V., Vimeux, F., Jouzel, J., Morgan, V., Delmotte, M., Ciais, P., Hammer, C., Johnsen, S., Lipenkov, V. Y., MosleyThompson, E., Petit, J.-R., Steig, E. J., Stievenard, M., and Vaikmae, R.: Holocene Climate Variability in Antarctica Based on 11 Ice-Core Isotopic Records, Quaternary Res., 54, 348-358, 2000.

Masson-Delmotte, V., Stenni, B., and Jouzel, J.: Common millennial-scale variability of Antarctic and Southern Ocean temperatures during the past 5000 years reconstructed from the EPICA Dome C ice core, Holocene, 14, 145-151, 2004.

Masson-Delmotte, V., Hou, S., Ekaykin, A., Jouzel, J., Aristarain, A., Bernardo, R. T., Bromwhich, D., Cattani, O., Delmotte, M., Falourd, S., Frezzotti, M., Gallée, H., Genoni, L., Isaksson, E., Landais, A., Helsen, M., Hoffmann, G., Lopez, J., Morgan, V., Motoyama, H., Noone, D., Oerter, H., Petit, J. R., Royer, A., Uemura, R., Schmidt, G. A., Schlosser, E., Simões, J. C., Steig, E., Stenni, B., Stievenard, M., van den Broeke, M., van de Wal, R., van de Berg, W.-J., Vimeux, F., and White, J. W. C.: A review of Antarctic surface snow isotopic composition : observations, atmospheric circulation and isotopic modelling, J. Climate, 21, 3359-3387, 2008.

Masson-Delmotte, V., Stenni, B., Blunier, T., Cattani, O., Chappellaz, J., Cheng, H., Dreyfus, G., Edwards, R. L., Falourd, S., Govin, A., Kawamura, K., Johnsen, S. J., Jouzel, J., Landais, A., Lemieux-Dudon, B., Lourantou, A., Marshall, G. J., Minster, B., Mudelsee, M., Pol, K., Rothlisberger, R., Selmo, E., and Waelbroeck, C.: An abrupt change of Antarctic moisture origin at the 
end of termination II, P. Natl. Acad. Sci., 107, 12091-12094, doi:10.1073/pnas.0914536107, 2010.

Masson-Delmotte, V., Buiron, D., Ekaykin, A., Frezzotti, M., Gallée, H., Jouzel, J., Krinner, G., Landais, A., Motoyama, H., Oerter, H., Pol, K., Pollard, D., Ritz, C., Schlosser, E., Sime, L. C., Sodemann, H., Stenni, B., Uemura, R., and Vimeux, F.: A comparison of the present and last interglacial periods in six Antarctic ice cores, Clim. Past, 7, 397-423, doi:10.5194/cp-7397-2011, 2011.

McGlone, M. S., Turney, C. S. M., Wilmshurt, J. M., Renwick, R., and Pahnke, K.: Divergent trends in land and ocean temperature in the southern Ocean over the past 18,000 years, Nat. Geosci., 3, 622-626, 2010.

Mulvaney, R., Abram, N. J., Hindmarsh, R. C. A., Arrowsmith, C., Fleet, L., Triest, J., Sime, L. C., Alemany, O., and Foord, S.: Recent Antarctic Peninsula warming relative to Holocene climate and ice-shelf history, Nature, 489, 141-144, 2012.

Nielsen, S. H. H., Koc, N., and Crosta, X.: Holocene climate in the Atlantic sector of the Southern Ocean: Controlled by insolation or oceanic circulation?, Geology, 32, 317-320, doi:10.1130/G20334.1, 2004.

Nikolaiev, V. I., Kotlyakov, V. M., and Smirnov, K. E.: Isotopic studies of the ice core from the Komsomolskaia station, Antarctica, Data of Glaciological Studies of the USSR Academy of Sciences, 63, 97-102, 1988.

Opsteegh, J. D., Haarsma, R. J., Selten, F. M., and Kattenberg, A.: ECBilt: A dynamic alternative to mixed boundary conditions in ocean models, Tellus A, 50, 348-367, 1998.

Pahnke, K. and Sachs, P.: Sea surface temperature of southern midlatitudes 0-160 kyr BP, Paleoceanograpgy, 21, PA2003, doi:10.1029/2005PA001191, 2006.

Peltier, W. R.: Global glacial isostay and the surface of the ice-age earth: The ICE-5G (VM2) Model and GRACE, Annu. Rev. Earth Planet Sc., 32, 111-149, doi:10.1146/annurev.earth.32.082503.144359, 2004.

Pike, J., Swann, G. E. A., Leng, M. J., and Snelling, A. M.: Glacial discharge along the west Antarctic Peninsula during the Holocene, Nat. Geosci., online first, doi:10.1038/ngeo1703, 2013.

Pichon, J.-J.: Les diatomées traceurs de l'évolution climatique et hydrologique de l'Océan Austral au cours du dernier cycle climatique, PhD Thesis, Université Bordeaux 1, 279 pp., 1985

Pollard, D. and DeConto, R. M.: Modelling West Antarctic ice sheet growth and collapse through the past five million years, Nature, 458, 329-332, 2009.

Renssen, H., Goosse, H., Fichefet, T., Masson-Delmotte, V., and Koc, N.: The Holocene climate evolution in the high-latitude Southern Hemisphere simulated by a coupled atmosphere-sea ice-ocean-vegetation model, Holocene, 15, 951-964, 2005.

Renssen, H., Seppä, H., Heiri, O., Roche, D. M., Goosse, H., and Fichefet, T.: The spatial and temporal complexity of the Holocene thermal maximum, Nat. Geosci., 2, 411-414, doi:10.1038/NGEO513, 2009.

Renssen, H., Goosse, H., Crosta, X., and Roche, D. M.: Early Holocene Laurentide Ice Sheet deglaciation causes cooling in the high-latitude Southern Hemisphere through oceanic teleconnection, Paleoceanography, 25, PA3204, doi:10.1029/2009PA001854, 2010.
Salvignac, M.-E.: Variabilité hydrologique et climatique dans l'Océan Austral (secteur indien) au cours du Quaternaire terminal, Essai de corre lations inter-hémisphériques, $\mathrm{PhD}$. Thesis, Université Bordeaux 1, 308 pp., 1998.

Schmidt, G. A., Jungclaus, J. H., Ammann, C. M., Bard, E., Braconnot, P., Crowley, T. J., Delaygue, G., Joos, F., Krivova, N. A., Muscheler, R., Otto-Bliesner, B. L., Pongratz, J., Shindell, D. T., Solanki, S. K., Steinhilber, F., and Vieira, L. E. A.: Climate forcing reconstructions for use in PMIP simulations of the last millennium (v1.0), Geosci. Model Dev., 4, 33-45, doi:10.5194/gmd4-33-2011, 2011.

Schoof, C.: Ice sheet grounding line dynamics: Steady states, stability, and hysteresis, J. Geophys. Res., 112, F03S28, doi:10.1029/2006JF000664, 2007.

Shakun, J. D., Clark, P. U., He, F., Marcott, P. U., Mix, A. C., Liu, Z., Otto-Bliesner, B., Schmittner, A., and Bard, E.: Global warming preceded by increasing carbon dioxide concentrations during the last deglaciation, Nature, 484, 49-54, 2012.

Shevenell, A. E., Ingalls, A. E., Domack, E. W., and Kelly, C.: Holocene Southern Ocean surface temperature variability west of the Antarctic Peninsula, Nature, 470, 250-254, 2011.

Sidall, M., Milne, G. A., and Masson-Delmotte, V.: Uncertainties in elevation changes and their impact on Antarctic temperature records since the end of the last glacial period, Earth Planet. Sc. Lett., 315-316, 12-23, 2012.

Sime, L. C., Tindall, J. C., Wolff, E. W., Connolley, W., and Valdes, P. J.: Antarctic isotopic thermometer during a $\mathrm{CO}_{2}$ forced warming, J. Geophys. Res., 113, D24119, doi:10.1029/2008JD010395, 2008.

Spence, P., Saenko, O., Sijp, W., and England, M.: North Atlantic climate response to Lake Agassiz drainage at coarse and ocean eddy-permitting resolutions, J. Climate, online first, doi:10.1175/JCLI-D-11-00683.1, 2012.

Steig, E., Brook, E. J., White, J. W. C., Sucher, C. M., Bender, M. L., Lehman, S. J., Morse, D. L., Waddigton, E. D., and Clow, G. D.: Synchronous climate changes in Antarctica and the North Atlantic, Science, 282, 92-95, 1998.

Stenni, B., Buiron, D., Frezzotti, M., Albani, S., Barbante, C., Bard, E., Barnola, J. M., Baroni, C., Baumgartner, S., Bonazza, M., Capron, E., Castellano, E., Chappellaz, J., Delmonte, B., Falourd, S., Genoni, L., Iacumin, P., Jouzel, J., Kipfsthul, J., Landais, A., Lemieux-Dudon, B., Maggi, V., Masson-Delmotte, V., Mazzola, C., Minster, B., Montagnat, M., Mulvaney, R., Narcisi, B., Oerter, H., Parrenin, F., Petit, J. R., Ritz, C., Scarchilli, C., Schilt, A., Schüpbach, E., Schwander, J., Selmo, E., Severi, M., Stocker, T., and Udisti, R.: The expression of the bipolar climate seesaw around Antarctica during the last deglaciation, Nat. Geosci., 4, 46-49, 2011.

Stone, J. O., Balco, G. A., Sugden, D. E., Caffee, M. W., Sass, L. C., Cowdery, S. G., and Siddoway, C.: Holocene deglaciation of Marie Byrd Land, West Antarctica, Science, 299, 99-102, 2003.

Stocker, T. F.: The seesaw effect, Science, 282, 61-62, 1998.

Swingedouw, D., Fichefet, T., Goosse, H., and Loutre, M. F.: Impact of transient freshwater releases in the Southern Ocean on the AMOC and climate, Clim. Dynam., 33, 365-381, doi:10.1007/s00382-008-0496-1, 2009.

Van Leeuwen, P. J.: Particle filtering in Geophysical Systems, Mon. Weather Rev., 137, 4089-4114, 2009. 
Verkulich, S. R., Melles, M., Hubberten, H.-W., and Pushina, Z. V.: Holocene environmental changes and development of Figurnoye Lake in the southern Bunger Hills, East Antarctica, J. Paleolimnol., 28, 253-267, 2002.

Vimeux, F., Masson, V., Jouzel, J., Stievenard, M., and Petit, J. R.: Glacial-interglacial changes in ocean surface conditions in the Southern Hemisphere, Nature, 398, 410-413, 1999.
Watanabe, O., Jouzel, J., Johnsen, S., Parrenin, F., Shoji, H., and Yoshida, N.: Homogeneous climate variability across East Antarctica over the past three glacial cycles, Nature, 422, 509512, 2003.

Widmann, M., Goosse, H., van der Schrier, G., Schnur, R., and Barkmeijer, J.: Using data assimilation to study extratropical Northern Hemisphere climate over the last millennium, Clim. Past, 6, 627-644, doi:10.5194/cp-6-627-2010, 2010. 